\title{
IODP Expeditions 303 and 306 Monitor Miocene- Quaternary Climate in the North Atlantic
}

by James E.T. Channell, Tokiyuki Sato, Toshiya Kanamatsu, Rüdiger Stein, Mitchell Malone, Carlos Alvarez-Zarikian, and the IODP Expeditions 303 and 306 Scientists

doi:10.2204/iodp.sd.2.01.2006

\section{Introduction}

The IODP Expeditions 303 and 306 drilling sites were chosen for two reasons: (1) to capture Miocene-Quaternary millennial-scale climate variability in sensitive regions at the mouth of the Labrador Sea and in the North Atlantic icerafted debris (IRD) belt (Ruddiman et al., 1977), and (2) to provide the sedimentary and paleomagnetic attributes, including adequate sedimentation rates, for constructing high-resolution isotopic and magnetic stratigraphies.

High accumulation rates, reaching $20 \mathrm{~cm} \mathrm{ky}^{-1}$, permit the study of millennial-scale variations in climate and in the Earth's magnetic field over the past several million years, when the amplitude and frequency of climate variability changed substantially. Shipboard logging and scanning data (magnetic susceptibility and remanence, density, natural gamma radiation, digital images and color reflectance) and post-expedition x-ray fluorescence (XRF) scanning data

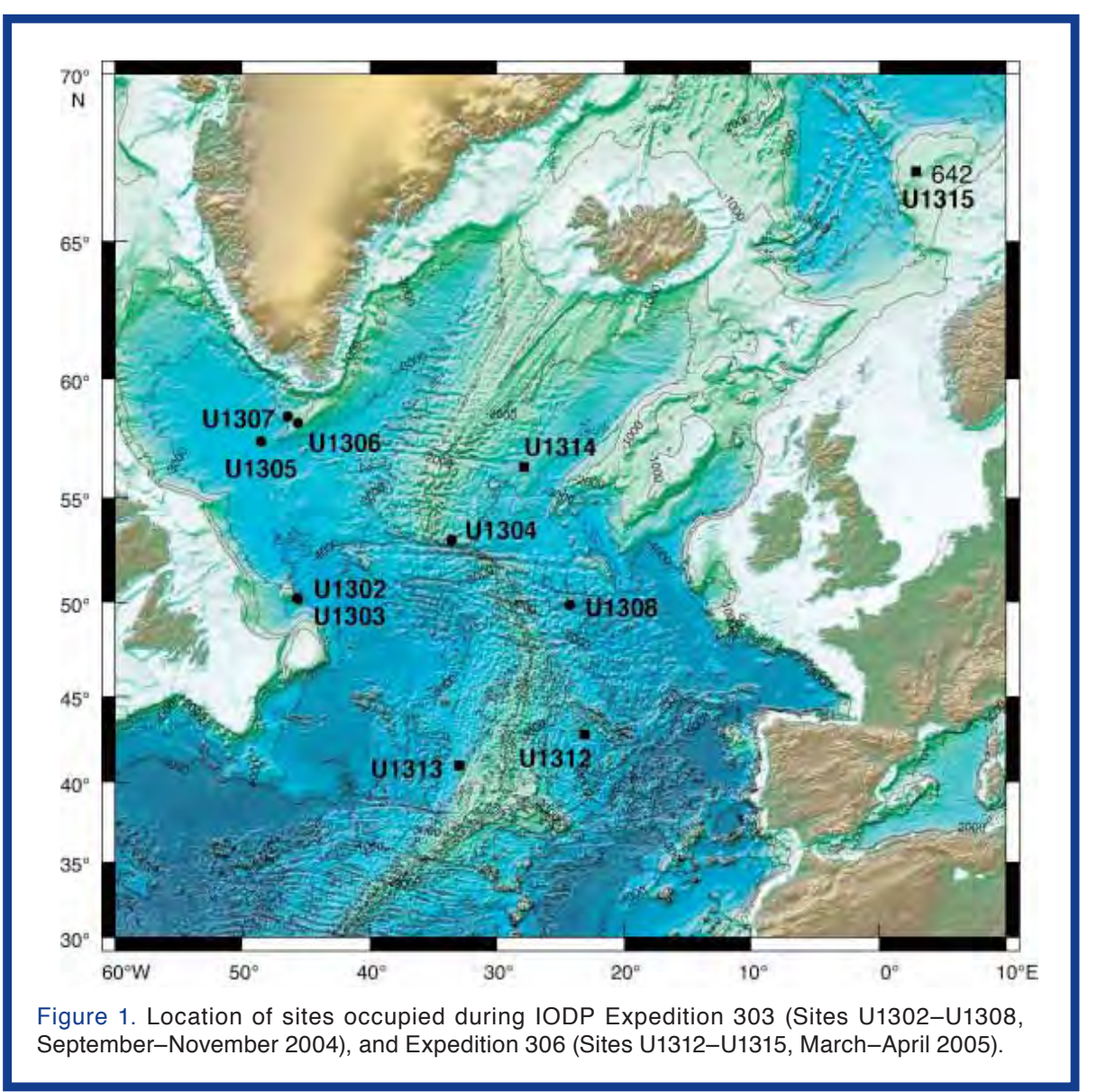

have revealed that the sediment cores recovered on Expeditions 303 and 306 contain detailed histories of millennial-scale climate and geomagnetic field variability throughout the late Miocene to Quaternary epochs. The climate proxies will be integrated with paleomagnetic data to place the records of millennial-scale climate change into a high resolution stratigraphy based on oxygen isotope and relative paleomagnetic intensity (RPI). The paleomagnetic record of polarity reversals, excursions and RPI in these cores is central to the construction of the stratigraphic template and will provide detailed documentation of geomagnetic field behavior.

\section{Background and Goals}

The discovery of climatic oscillations in the Greenland ice cores, the so-called "Dansgaard-Oeschger" (D-O) events, demonstrated that large temperature changes had occurred over Greenland during the last glaciation (Johnsen et al., 1992; Dansgaard et al., 1993; Grootes et al., 1993). The abruptness of these events was impressive, occurring on timescales as short as decades to centuries. Broecker et al. (1992) proposed that layers of IRD-containing detrital carbonate (termed "Heinrich events" after Heinrich, 1988) in North Atlantic sediments were derived from massive discharges of ice from the Hudson Straits region. Over the past fifteen years, this hypothesis spawned numerous studies on IRD in the North Atlantic Ocean (for reviews, see Andrews, 1998, 2000; Hemming, 2004). Most significant were those by Bond and colleagues who linked Heinrich events and other IRD events from North Atlantic sediment cores with temperature oscillations in Greenland (Bond et al., 1992, 1993; McManus et al., 1994; Bond and Lotti, 1995). Higher frequency variations were found to be superimposed upon these signals. These variations were apparent in IRD components such as hematite-stained grains and Icelandic glass and have $\sim 1500$ yr pacing (Bond and Lotti, 1995; Bond et al., 1999b, 2001). 
Millennial-scale climate variability has been well documented for the last glacial cycle, most notably in ice cores from Greenland that extend back $123 \mathrm{ky}$ (North Greenland Ice Core project members, 2004). Studies of deep-sea sequences indicate that high-frequency climate variability was also prevalent prior to this period (Oppo et al., 1998; Raymo et al., 1998; McManus et al., 1999; Hiscott et al., 2001; de Abreu et al., 2003; Martrat et al., 2004), but such studies have been limited by the availability of long cores with high sedimentation rates. During IODP Expeditions 303 and 306, we recovered cores from multiple locations in the North Atlantic (Fig. 1) that are well suited for examining suborbital climate variability beyond the last glacial-interglacial climate cycle.

The results of this drilling will address significant climateand geomagnetic-related questions such as the following.

1. When did Heinrich events first appear in the sedimentary record of the North Atlantic?

2. Was millennial-scale climate variability fundamentally different in magnitude or pacing before the mid-Pleistocene transition from 41-ky to $100-k y$ glacial cycles?

3. How have horizontal and vertical gradients in surface- and deep-water mass properties changed on both orbital and millennial time scales?

4. Is the 1500-yr pacing documented for the last climate cycle a stable feature of the North Atlantic throughout the Pleistocene?

5. Can the promise of RPI as documented during the last glacial cycle be extended and linked to marine isotope stages to provide a viable means of global correlation?

6. Can offsets in benthic $\delta^{18} \mathrm{O}$ records, due to local deep-water $\delta^{18} \mathrm{O}$ and temperature (e.g. Skinner and Shackleton, 2005), be resolved using RPI as a stratigraphic tool?

7. How can lithologic contamination in RPI records be minimized, and can periodicities in those records be attributed to geomagnetic behavior?

8. What was the morphology of the geomagnetic field during reversals, excursions and brief subchrons?

9. As geomagnetic field intensity is a control on cosmogenic nuclide production, does the correlation of North Atlantic climate or IRD cycles to cosmogenic isotope flux (Bond et al., 2001) imply a link between climate and geomagnetic field strength, or between climate and solar activity?

\section{Sedimentary Sections Recovered During IODP Expeditions 303 and 306}

The primary objectives of IODP Expeditions 303 and 306 (Fig. 1) were to recover cores that would yield complete and continuous records of millennial-scale environmental variability (i.e., ice sheet-ocean interactions, deep circulation changes and sea-surface conditions), and also be suitable for the development of high-resolution magnetic and isotope stratigraphies. Many of these study sites have been instrumental in developing marine records of suborbital climate variability for the last climate cycle (e.g., Orphan Knoll, Eirik and Gardar Drifts, and DSDP Sites 607, 608, and 609). Emphasis was placed on the recovery of complete, undisturbed, composite sections from multiple advanced piston corer (APC) holes. Shipboard data and post-cruise XRF scanning of the recovered cores appear to document millennial-scale variability that extends through the last several million years.

At each site, drilling was terminated at the limit of the APC. The extended core barrel (XCB) was not used because the increase in drilling disturbance associated with the $\mathrm{XCB}$, particularly in the upper part of the $\mathrm{XCB}$ section, is not conducive to highresolution studies, and because previous DSDP or ODP drilling legs have sampled the deeper stratigraphic section at all locations other than the Gardar Drift sites.

Sites U1302 and U1303 are located close to Orphan Knoll on the Labrador Rise (Fig. 1), where proximal records of Laurentide ice-sheet (LIS) instability are manifest in detrital layer stratigraphy. Piston cores collected at or near Sites U1302 and U1303 (HU91-045-094P, MD95-2024, MD95-2025, MD99-2237) preserve a detailed stratigraphic record of LIS instability through detrital carbonate-rich and -poor layers (Hillaire-Marcel et al., 1994; Stoner et al., 1996, 1998; 2000; Hillaire-Marcel and Bilodeau, 2000; Hiscott et al., 2001). Isotopic data from planktic foraminifers indicate that these detrital layers are associated with large depletions in $\partial^{18} \mathrm{O}$ that likely reflect significant meltwater incursions. Sites U1302 and U1303 record these detrital layers (e.g., see Fig. 2) and provide an opportunity to document LIS instability and its intercalibration with oxygen isotopes and RPI, to the base of the recovered section, or approximately marine isotopic stage (MIS) 17 (Fig. 3). Mean sedimentation rates for the upper $105 \mathrm{~m}$ at Sites U1302 and U1303 are estimated to be $\sim 15 \mathrm{~cm} \mathrm{ky}^{-1}$. 
Site U1304 is located at the southern tip of the Gardar Drift and the northern end of the central Atlantic IRD belt, near the Gibbs Fracture Zone (Fig. 1). It provides a more distal record of LIS instability compared to Sites U1302 and U1303, and it lies in sufficiently deep water $(3065 \mathrm{~m})$ to document lower North Atlantic Deep Water (NADW) variability. Site U1304 also complements ODP Site 983, which was drilled at an intermediate water depth (1983 m) on the northern Gardar Drift. The sediments at Site U1304 comprise interbedded diatom and nannofossil oozes with clay and silty clay. The lithologies are generally interbedded on centimeter to decimeter scales. Diatom assemblages are dominated by needle-shaped species of the ThalassiothrixLioloma complex. The diatom-rich sedimentary section extends to the uppermost Pliocene at $258 \mathrm{mcd}$ (Fig. 3). Mean sedimentation rates of $17.8 \mathrm{~cm} \mathrm{ky}^{-1}$ are estimated for the last $0.78 \mathrm{Ma}$, and $12.2 \mathrm{~cm} \mathrm{ky}^{-1}$ for the interval from 0.78 to $1.77 \mathrm{Ma}$. The episodic occurrence of diatom-rich strata implies that the site has been located near the sub-arctic convergence related to the confluence of the Labrador and North Atlantic Currents (see Boden and Backman, 1996). The good preservation of benthic and planktic foraminifers, the excellent magnetic properties apparent from shipboard data and the construction of a complete composite section from four holes indicate that the environmental record can be placed into a reliable and precise age model.
Sites U1305, U1306 and U1307 were drilled on the Eirik Drift (Fig. 1). Site U1305 was the designated deep-water site in $3459 \mathrm{~m}$ water depth at the western extremity of the Eirik Drift, and Site U1306 was the primary shallow-water site in $2273 \mathrm{~m}$ water depth, located $191 \mathrm{~km}$ northeast of Site U1305. These two sites were chosen by maximizing the thickness of the Quaternary sedimentary section in the multichannel seismic (MCS) network obtained over the Eirik Drift during Cruise KN166-14 of the R/V Knorr in 2002, whereas Site 1307 is located where the Quaternary sedimentary section appears to be thinned relative to its thickness at Site U1306, providing APC access to the underlying Pliocene section. Conventional piston cores have shown that the sedimentation history on the Eirik Drift during the last glacial cycle was strongly affected by the Western Boundary Undercurrent (WBUC) that sweeps along east Greenland and into the Labrador Sea (Hillaire-Marcel et al., 1994; Stoner et al., 1998). Data from two such piston cores (HU90-013-013 and HU90-013-012) from contrasting water depths suggested that Site U1305 should display relatively expanded interglacials and relatively condensed glacial intervals, and that Site 1306 should show the the converse. The base of the section at both sites lies within or just below the Olduvai Subchronozone at 300 mcd (Fig. 3), and the mean sedimentation rates were $17-18 \mathrm{~cm}$ ky-1. Sites U1305 and U1306 will provide complementary high-resolution records of the history of the WBUC detrital layer stratigraphy signifying

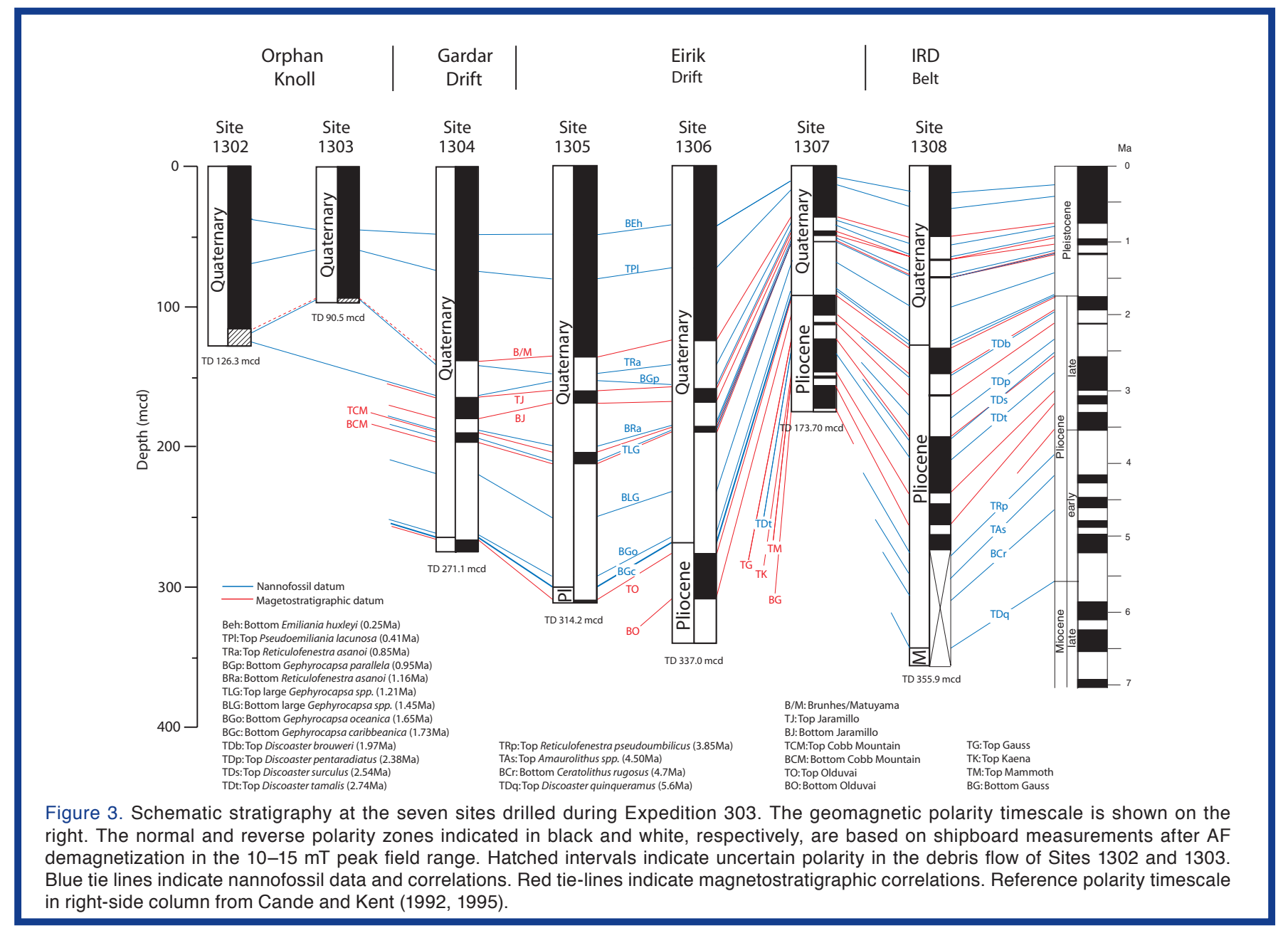


instability of the surrounding ice sheets, and the attributes for well-constrained age models using stable isotopes, biostratigraphy and RPI. Two holes were drilled at Site U1307 reaching a maximum depth of $162 \mathrm{mcd}$ in the uppermost Gilbert Chronozone ( 3.6 Ma) (Fig. 3). The mean sedimentation rate for the recovered section was $4.9 \mathrm{~cm} \mathrm{ky}^{-1}$. Interval sedimentation rates between polarity reversals ranged from 2.7 to $7.6 \mathrm{~cm} \mathrm{ky}^{-1}$. Poor weather and excessive ship heave curtailed drilling at this site, and the two holes were insufficient to generate a complete composite section. The site did, however, establish the feasibility of recovering the Pliocene sedimentary section on the Eirik Drift using the APC. The site extends the environmental record back to $\sim 3.6 \mathrm{Ma}$ and will provide invaluable age control throughout the MCS network established on the Eirik Drift by the KN166-14 cruise. The cores recovered at Site U1307 thus will enhance our understanding of the sedimentary architecture of the Eirik Drift.

Site U1308 represents a reoccupation of DSDP Site 609, which has played a prominent role in some of the most important developments in millennial-scale climate research during the past fifteen years. IRD layers containing detrital carbonate (Heinrich events) were recognized at this site (Bond et al., 1992); they also correlated to the Greenland icecore record (e.g., Bond et al., 1993). The 1500-yr cycle in petrologic characteristics such as hematite-stained grains and Icelandic glass has also been recognized at this site (Bond et al., 1999b). Most of the recent work on DSDP Site 609 sediments has focused on the last glacial cycle, partly because of uncertainties in the continuity of the section at greater depth. Site U1308 has improved upon Site 609 in that a complete composite section was obtained to $247 \mathrm{mcd}$, with its base within the Gauss Chronozone at $\sim 3.1$ Ma (Fig. 3). Sedimentation rates averaged $7.9 \mathrm{~cm} \mathrm{ky}^{-1}$ over the entire period.

Site U1312 represents a reoccupation of DSDP Site 608 (Fig. 1). The main objective was to obtain continuous records of surface- and deep-water characteristics and their interactions with proxies for ice-sheet instability during NeogeneQuaternary times. In this context, an important target at this site was the recovery of a complete, undisturbed, upper Miocene section by APC. The Holocene to upper Miocene sedimentary sequence at Site U1312 consists of varying mixtures of biogenic and detrital components, primarily nannofossils, foraminifers and clay minerals. Near 3.5 Ma, the progressive but oscillatory deterioration of the Northern Hemisphere climate, which gradually led to the onset of major continental ice sheets at about $2.7 \mathrm{Ma}$, is reflected in the increase in detrital sediment input, followed by climatecontrolled, short-term variability in detrital input in the latePliocene to Pleistocene. Average sedimentation rates were low (1-2 cm ky-1) during the late Miocene, the late Pliocene,

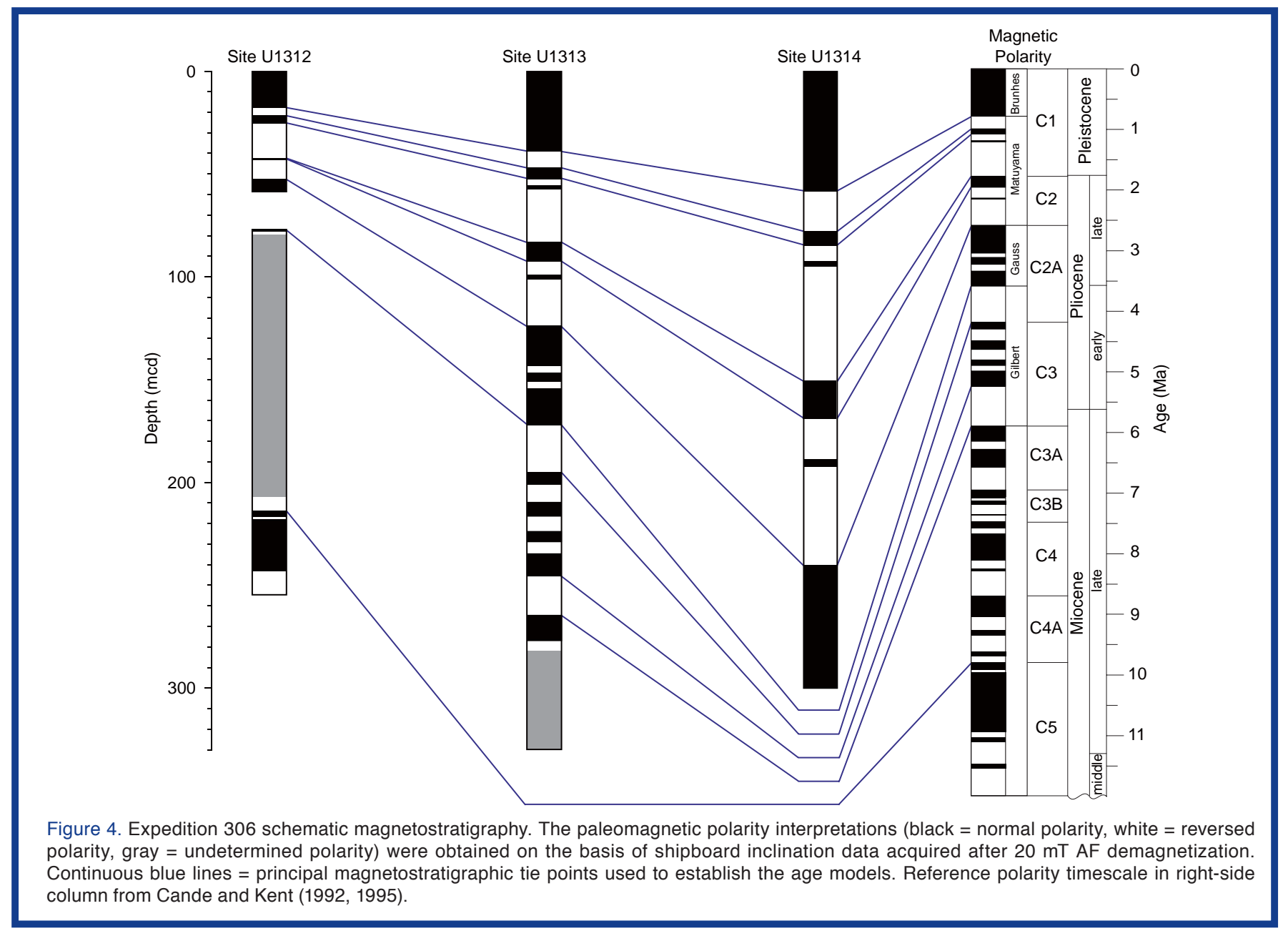


and the Pleistocene, but higher in the early Pliocene $(3-8 \mathrm{~cm}$ $\left.\mathrm{ky}^{-1}\right)$. The sedimentary sequence of Site U1312 representing approximately the last $11 \mathrm{My}$ (Fig. 4) will allow the study of short- and long-term climate variability and oceanatmosphere interactions under very different boundary conditions, such as the closure and re-opening of AtlanticMediterranean connections at the end of the Miocene (6-5 Ma), the closing of the Isthmus of Panama (4.5-3 Ma), and the onset of major Northern Hemisphere glaciation near $2.7 \mathrm{Ma}$.

Site U1313 represents a reoccupation of DSDP Site 607 (Fig. 1). Site 607 has been very important for generating a late Pliocene to Pleistocene stable isotope stratigraphy and for interpreting it in terms of ice-sheet variability and changes in NADW circulation. At the site of Core VM 30-97, located close to DSDP Site 607, Heinrich events are marked by the distinctive detrital carbonate signature, and planktonic foraminifer-derived sea-surface temperatures warmed markedly during the Heinrich events and during the Last Glacial Maximum, in distinct contrast to the climate records from the sub-polar North Atlantic (Bond et al., 1999a). The Holocene to latest Miocene sediment at Site U1313 (Fig. 4) consists primarily of nannofossil ooze with varying amounts of foraminifers and clay- to gravel-sized terrigenous components. The detrital components become much more important and variable in the upper Pliocene-Pleistocene interval of the sequence, probably reflecting Northern Hemisphere icesheet instability. Bio- and magneto-stratigraphy indicate nearly constant sedimentation rates of $\sim 4.1-4.5 \mathrm{~cm} \mathrm{ky}-1$ throughout the Pliocene-Pleistocene time interval, whereas in the late Messinian sedimentation rates were approximately $13-14 \mathrm{~cm} \mathrm{ky}^{-1}$. The correlation of downhole logging data with core data should allow the mapping of the spliced core record to actual depth, resulting in more accurate sedimentation rate calculations and more detailed age-depth models. Site U1313 provides a unique and complete PliocenePleistocene sedimentary section (Fig. 4) that will allow an optimal reconstruction of the phasing of the temperature records and its relationship to ice-sheet instability and changes in deep-water circulation since approximately $5 \mathrm{Ma}$. In addition, sedimentation rates of $13-14 \mathrm{~cm} \mathrm{ky}^{-1}$ will allow a high-resolution study of paleoenvironmental change during the late Messinian.

Site U1314 was drilled on the southern Gardar Drift (Fig. 1) at a water depth of approximately $2800 \mathrm{~m}$. The complete upper Pliocene to Holocene sedimentary sequence recovered at this site (Fig. 4) consists of an alternation of predominantly nannofossil oozes enriched in biogenic and terrigenous components, and terrigenous silty clay with a varying proportion of calcareous and siliceous organisms. This alternation is also reflected in the varying carbonate content between $\sim 5 \%$ and $70 \%$. Sand- and gravel-sized sediment, common at Site U1314 from 0 to 240 mbsf, provides direct evidence of ice rafting and documents the influence of PlioPleistocene glaciations in this region. Site U1314 yields abundant moderately to well-preserved assemblages of calcareous and siliceous microfossils throughout the section and an excellent paleomagnetic record of the Brunhes, Matuyama and the upper part of the Gauss Chrons. Several brief geomagnetic excursions are present in the paleomagnetic record. Sedimentation rates based on microfossil data and polarity reversals indicate decreasing rates from approximately 11-11.5 $\mathrm{cm} \mathrm{ky}^{-1}$ during the late Pliocene, to $\sim 7.0-7.5 \mathrm{~cm} \mathrm{ky}^{-1}$ during the Pleistocene. Due to its proximity to the IRD belt and within the NADW, the complete upper Pliocene to Holocene sequence at Site U1314 (Fig. 4) will establish a high-resolution paleoenvironmental record of sea-surface and bottom-water characteristics and a detrital (Heinrich-type) stratigraphy for the past $\sim 2.7 \mathrm{Ma}$.

Site U1315 is located on the Vøring Plateau close to ODP Site 642 (Fig. 1). At this site, a borehole observatory for longterm measurements of bottom-water temperatures was installed in a newly drilled 180-m-deep hole (see progress report p. 28). The hole was sealed from the overlying ocean after two pressure cases and a thermistor string were installed. This configuration allows high-precision temperature measurements as a function of both depth and time. The sub-bottom temperature perturbations should allow reconstruction of the temperature record of bottom water during at least the last 100 years, far beyond the directly measured temperature records available up to now.

\section{Summary}

Long-term records of millennial-scale variability from North Atlantic proxies of surface temperature, ice-sheet dynamics and thermohaline circulation provide valuable constraints on the nature of atmosphere-ice-ocean interactions that are responsible for abrupt climate change (e.g., Alley et al., 1999). The overall post-cruise objectives of IODP Expeditions 303 and 306 are to resolve the climate records from the high-sedimentation-rate sedimentary sections that have been recovered, and to generate a stratigraphic framework based on biostratigraphy, oxygen isotope data and magnetic stratigraphy, including RPI data. The integrated stratigraphy will allow the climate record, such as the detrital layer stratigraphy indicative of ice-sheet instability, to be placed in a suitable framework for correlating North Atlantic climate records to one another and to high-resolution records elsewhere. The power of shipboard whole-core logging data (susceptibility, natural gamma, digital image, reflectance, and density) and shore-based scanning data (e.g. XRF) means that the basic climate-related lithologic variability (e.g. detrital layers) can be recognized throughout the late Miocene-Quaternary. The key is placing this detrital record and other climate proxies (e.g. stable isotopic data for deepand surface-water mass temperature and chemistry, faunal and floral overturn, etc.) into a precise stratigraphic framework. This stratigraphic framework is essential for meeting the objectives of Expeditions 303 and 306, and for studying millennial-scale climate change on long timescales. 


\section{IODP Expedition 303 Scientists}

J. Channell (Co-Chief Scientist), T. Sato (Co-Chief Scientist), M. Malone (Expedition Project Manager/Staff Scientist), S. Robinson, G. Bartoli, S. Chiyonobu, J.(Jed) E. Damuth, L. de Abreu, A. De Vernal, A. Ennyu, E. Esmerode, S. Funakawa, S. Henderson, D. Hodell, M. Ito, K. Kawamura, N. Kawamura, L. Krissek, S. Leigh, C. Liu, A. Mazaud, S. Obrochta, O. Romero, R. Schiebel, C. Shimada, J. Stoner, R. Wilkens, J. Wright, M. Yamasaki.

\section{IODP Expedition 306 Scientists}

T. Kanamatsu (Co-Chief Scientist), R. Stein (Co-Chief Scientist), C. Alvarez-Zarikian, (Expedition Project Manager/ Staff Scientist), S. Higgins, E. Aboud, G. Acton, K.Akimoto, I. Bailey, K. Bjørklund, H. Evans, N. Fang, P. Ferretti, J. Gruetzner, Y. Guyodo, K. Hatakeda, R. Harris, K. Hagino, J. Hefter, S. Judge, D. Kulhanek, F. Nanayama, S. Nielsen, M. Ohno, H. Rashid, F. S. Sanchez, A. Voelker, Q. Zhai.

\section{References}

Alley, R.B., Clark, P.U., Keigwin, L.D., and Webb, R.S., 1999. Making sense of millennial-scale climate change. In Clark, P.U., Webb, R.S., and Keigwin, L.D. (Eds.), Mechanisms of Global Climate Change at Millennial Time Scales. Geophys. Monogr., 112:385-394.

Andrews, J.T., 1998. Abrupt changes (Heinrich events) in late Quaternary North Atlantic marine environments: a history and review of data and concepts. $J$. Quat. Sci., 13:3-16. doi:10.1002/(SICI)1099-1417 (199801/02)13:1<3::AID-JQS361>3.0.CO;2-0

Andrews, J.T., 2000. Icebergs and iceberg rafted detritus (IRD) in the North Atlantic: facts and assumptions. Oceanography, 13:100-108.

Bodén, P., and Backman, J., 1996. A laminated sediment sequence from northern North Atlantic Ocean and its climatic record. Geology, 24:507-510. doi:10.1130/ 0091-7613(1996)024<0507:ALSSFT>2.3.CO;2

Bond, G., Kromer, B., Beer, J., Muscheler, R., Evans, M.N., Showers, W., Hoffmann, S., Lotti-Bond, R., Hajdas, I., and Bonani, G., 2001. Persistent solar influence on North Atlantic climate during the Holocene. Science, 294:2130-2136.

doi:10.1126/science. 1065680

Bond, G., Showers, W., and Lynch-Steiglitz, J., 1999a. Are major shifts in thermohaline circulation revealed in North Atlantic and South Atlantic antiphased climate patterns? Eos, Trans. Am. Geophys. Union, 80(17):S169. (Abstract)

Bond, G.C., Broecker, W., Johnsen, S., McManus, J., Labeyrie, L., Jouzel, J., and Bonani, G., 1993. Correlations between climate records from North Atlantic sediments and Greenland ice. Nature (London, U. K.), 365:143-147.

Bond, G.C., Heinrich, H., Broecker, W.S., Labeyrie, L.D., McManus, J., Andrews, J., Huon, S., Janitschik, R.,
Clasen, S., Simet, C., Tedesco, K., Klas, M., Bonani, G., and Ivy, S., 1992. Evidence for massive discharges of icebergs into the North Atlantic ocean during the last glacial period. Nature (London, $U$. K.), 360:245-249.

Bond, G.C., and Lotti, R., 1995. Iceberg discharges into the North Atlantic on millennial time scales during the last glaciation. Science, 276:1005-1010.

Bond, G.C., Showers, W., Elliot, M., Evans, M., Lotti, R., Hajdas, I., Bonani, G., and Johnson, S., 1999b. The North Atlantic's 1-2 kyr climate rhythm: relation to Heinrich events, Dansgaard/Oeschger cycles and the Little Ice Age. In Clark, P.U., Webb, R.S., and Keigwin, L.D. (Eds.), Mechanisms of Global Climate Change at Millennial Time Scales. Geophys. Monogr., 112:35-58.

Broecker, W., Bond, G.C., Klas, M., Clark, E., and McManus, J., 1992. Origin of the northern Atlantic's Heinrich events. Clim. Dyn., 6:265-273.

Cande, S.C., and Kent, D.V., 1992. A new geomagnetic polarity time scale for the Late Cretaceous and Cenozoic. J. Geophys. Res., 97(10):13917-13951.

Cande, S.C., and Kent, D.V., 1995. Revised calibration of the geomagnetic polarity timescale for the Late Cretaceous and Cenozoic. J. Geophys. Res., 100:60936095. doi:10.1029/94JB03098

Dansgaard, W., Johnsen, S.J., Clausen, H.B., Dahl-Jensen, D., Gundestrup, N.S., Hammer, C.U., Hvidberg, C. S., Steffensen, J.P., Sveinbjörnsdottir, A.E., Jouzel, J., and Bond, G., 1993. Evidence for general instability of past climate from a 250-kyr ice-core record. Nature (London, U. K.), 364:218-220.

de Abreu, L., Shackleton, N.J., Schonfeld, J., Hall, M., and Chapman, M., 2003. Millennial-scale oceanic climate variability off the western Iberian margin during the last two glacial periods. Mar. Geol., 196:1-20. doi:10.1016/S0025-3227(03)00046-X

Grootes, P.M., Stuiver, M., White, J.W.C., Johnsen, S., and Jouzel, J., 1993. Comparison of oxygen isotope records from the GISP2 and GRIP Greenland ice cores. Nature (London, U. K.), 366:552-554. doi:10.1038/ $366552 \mathrm{a} 0$

Heinrich, H., 1988. Origin and consequences of cyclic ice rafting in the northeast Atlantic Ocean during the past 130,000 years. Quat. Res., 29:142-152. doi:10.1016/0033-5894(88)90057-9

Hemming, S.R., 2004. Heinrich events: massive late Pleistocene detritus layers of the North Atlantic and their global climate imprint. Rev. Geophys., 42:1-43. doi:10.1029/2003RG000128

Hillaire-Marcel, C., and Bilodeau, G., 2000. Instabilities in the Labrador Sea water mass structure during the last climatic cycle. Can. J. Earth Sci., 37:795-809. doi:10.1139/cjes-37-5-795

Hillaire-Marcel, C., De Vernal, A., Bilodeau, G., and Wu, G., 1994. Isotope stratigraphy, sedimentation rates, deep circulation, and carbonate events in the 
Labrador Sea during the last $\sim 200$ ka. Can. J. Earth Sci., 31:63-89.

Hiscott, R.N., Aksu, A.E., Mudie, P.J., and Parsons, D.F., 2001. A 340,000 year record of ice rafting, paleoclimatic fluctuations, and shelf-crossing glacial advances in the southwestern Labrador Sea. Global Planet. Change, 28:227-240. doi:10.1016/S09218181(00)00075-8

Johnsen, S.J., Clausen, H.B., Dansgaard, W., Fuhrer, K., Gundestrup, N., Hammer, C.U., Iversen, P., Jouzel, J., Stauffer, B., and Steffensen, J.P., 1992. Irregular glacial interstadials recorded in a new Greenland ice core. Nature (London, U. K.), 359:311-313.

Martrat, B., Grimalt, J.O., Lopez-Martinez, C., Cacho, I., Sierro, F.J., Flores, J.A., Zahn, R., Canals, M., Curtis, J.H., and Hodell, D.A., 2004. Abrupt temperature changes in the western Mediterranean over the past 250,000 years. Science, 306:1762-1765. doi:10.1126/ science.1101706

McManus, J., Bond, G., Broecker, W., Johnsen, S., Laybeyrie, L., and Higgins, S., 1994. High resolution climate records from the North Atlantic during the last interglacial. Nature (London, U. K.), 371:326-329. doi:10.1038/371326a0

McManus, J.F., Oppo, D.W., and Cullen, J.L., 1999. A 0.5 million year record of millennial-scale climate variability in the North Atlantic. Science, 283:971-975. doi:10.1126/science.283.5404.971

North Greenland Ice Core Project, 2004. High-resolution record of northern hemisphere climate extending into the last interglacial period. Nature (London, $U$. K.), 431:147-151.

Oppo, D.W., McManus, J.F., and Cullen, J.L., 1998. Abrupt climate events 500,000 to 340,000 years ago: evidence from subpolar North Atlantic sediments. Science, 279:1335-1338. doi:10.1126/science. 279.5355 .1335

Raymo, M.E., Ganley, K., Carter, S., Oppo, D.W., and McManus, J., 1998. Millenial-scale climate instability during the early Pleistocene epoch. Nature (London, U. K.), 392:699-702. doi:10.1038/33658

Ruddiman, W.F., 1977. Late Quaternary deposition of icerafted sand in the subpolar North Atlantic (Lat $40^{\circ} \mathrm{N}$ to $\left.65^{\circ} \mathrm{N}\right)$. Geol. Soc. Am. Bull., 88:1813-1827. doi:10.1130/0016-7606(1977)88<1813:LQDOIS> 2.0.CO;2

Skinner, L.C., and Shackleton, N.J., 2005. An Atlantic lead over Pacific deep-water change across Termination I: implications for the application of the marine isotope stage stratigraphy. Quat. Sci. Rev., 24:571-580. doi:10.1016/j.quascirev.2004.11.008

Stoner, J.S., Channell, J.E.T., and Hillaire-Marcel, C., 1996. The magnetic signature of rapidly deposited detrital layers from the deep Labrador Sea: relationship to North Atlantic Heinrich layers. Paleoceanography, 11:309-325. doi:10.1029/96PA00583
Stoner, J.S., Channell, J.E.T., and Hillaire-Marcel, C., 1998. A $200 \mathrm{ka}$ geomagnetic chronostratigraphy for the Labrador Sea: indirect correlation of the sediment record to SPECMAP. Earth Planet. Sci. Lett., 159:165-181. doi:10.1016/S0012-821X(98)00069-7

Stoner, J.S., Channell, J.E.T., Hillaire-Marcel, C., and Kissel, C., 2000. Geomagnetic paleointensity and environmental record from Labrador Sea Core MD95-2024: global marine sediment and ice core chronostratigraphy for the last 110 kyr. Earth Planet. Sci. Lett., 183:161-177. doi:10.1016/S0012-821X(00)00272-7

\section{Authors}

James E.T. Channell, Department of Geological Sciences, POB 112120, University of Florida, Gainesville, Fla. 32611, U.S.A., e-mail: jetc@geology.ufl.edu

Tokiyuki Sato, Institute of Applied Sciences, Mining College, Akita University, Tegata-Gakuencho 1-1, Akita 010 8502, Japan.

Toshiya Kanamatsu, Institute for Research on Earth Evolution, Japan Agency for Marine-Earth Science and Technology, 2-15 Natsushima-cho, Yokosuka, Kanagawa 236-0061, Japan.

Rüdiger Stein, Alfred-Wegener-Institut für Polar und Meeresforschung, Columbusstrasse 2, 27568 Bremerhaven, Germany.

Mitchell Malone, Integrated Ocean Drilling Program, Texas A\&M University, 1000 Discovery Drive, College Station, Texas 77845-9547, U.S.A.

Carlos Alvarez-Zarikian, Integrated Ocean Drilling Program, Texas A\&M University, 1000 Discovery Drive, College Station, Texas 77845-9547, U.S.A.

and the IODP Expeditions 303 and 306 Scientists

\section{Related Web Links}

http://iodp.tamu.edu/publications/PR/303PR/303PR.html http://iodp.tamu.edu/publications/PR/306PR/306PR.html

\section{Figure Credits}

Fig. 2 was compiled by Roy Wilkens. 